\title{
MALUNGOS E PARENTES: "SUMÁRIO CONTRA OS PRETOS DE ANGOLA DO CONTINENTE DE PERNAMBUCO" (1779)
}

Aldair Rodrigues ${ }^{1}$

\section{Resumo:}

Entre inúmeros processos e denúncias da Inquisição portuguesa conservados no Arquivo da Torre do Tombo, há o inédito "Sumário contra os pretos de Angola do continente de Pernambuco", de 1779, aqui transcrito e publicado. O documento é constituído por um conjunto de denúncias ricas em informações sobre as práticas sociais, culturais, identitárias e religiosas da comunidade formada em Pernambuco pelos africanos de nação Angola. Além disso, o Sumário oferece evidências sobre as dinâmicas subjacentes à emergência do vocábulo "Malungo" no léxico do português brasileiro do século XVIII.

Palavras-chaves: Malungo - práticas fúnebres - Angola - diáspora africana

\section{Abstract:}

Among the numerous cases and denunciations of the Portuguese Inquisition preserved in the Archive of Torre do Tombo, there is the unpublished "Summary against the Blacks of Angola of the Continent of Pernambuco" ("Sumário contra os pretos de Angola do continente de Pernambuco"), 1779, transcribed and published here. The document is constituted by a set of denunciations rich in information on the social, cultural, identity and religious practices of a community formed in Pernambuco by enslaved people from Angola. In addition, the document offers new evidence on the dynamics underlying the emergence of the word "Malungo" in the eighteenth-century Brazilian Portuguese lexicon.

Keyword: Shipmate - malungos - funeral practices - Angola - African diaspora

\section{INTRODUÇÃO}

Entre inúmeros processos e denúncias da Inquisição portuguesa conservados no Arquivo da Torre do Tombo, encontramos o inédito "Sumário contra os pretos de Angola do continente de Pernambuco"2, de 1779, aqui transcrito e publicado. O documento é constituído por um conjunto de denúncias ricas em informações sobre as práticas sociais, culturais, identitárias e religiosas da comunidade formada em Pernambuco pelos africanos de nação Angola. Além disso, o Sumário

1 Aldair Rodrigues é professor do departamento de História da UNICAMP, autor de Limpos de Sangue (Alameda, 2011) e Igreja e Inquisição no Brasil (Alameda, 2014). Atualmente dedica-se ao estudo da diáspora africana na América portuguesa do século XVIII.

2 Arquivo Nacional da Torre do Tombo (ANTT), Inquisição de Lisboa, Processo 4740, 1779. Daqui em diante: Sumário. 
oferece evidências sobre as dinâmicas subjacentes à emergência do vocábulo "Malungo" no léxico do português brasileiro do século XVIII.

Este estudo introdutório que acompanha a transcrição do documento tem por objetivo aproximar o leitor do contexto no qual as denúncias foram realizadas e indicar as suas potencialidades para a produção do conhecimento histórico acerca das experiências das comunidades africanas na diáspora.

\section{DESCRIÇÃO DA FONTE}

O sumário é composto por 5 fólios (frente e verso), reunindo documentos produzidos por quatro clérigos que atuavam em Lisboa e em Pernambuco. Por ordem cronológica, a primeira peça é a denúncia detalhada que foi redigida pelo padre Domingos de Oliveira Marques no dia 10 de fevereiro de 1779 .

A segunda é uma carta escrita por Manoel Félix da Cruz, comissário do Santo Ofício de Pernambuco, em 08 de abril de 1779. Além de endossar o teor da denúncia, ofereceu uma contextualização mais ampla da persistência das práticas rituais da comunidade angolana em sua jurisdição. Por ser comissário do Santo Ofício em um território que não sediava um tribunal inquisitorial, Cruz era a autoridade máxima da Inquisição, provavelmente foi quem remeteu os papéis para Lisboa. ${ }^{3}$

O documento seguinte é um requerimento do promotor de Lisboa, Jansen Moller, por meio do qual solicita aos inquisidores o castigo dos africanos para que "exemplarmente se atalhe e corte pela raiz tão horrorosa maldade".

Por fim, o escrivão Gregório Xavier Godinho informa que os juízes da Mesa da Inquisição de Lisboa haviam escrito ao governador de Pernambuco no dia 25 de novembro de 1779 com o fim de admoestá-lo para que que tomasse providências para "remediar a desordem" causada na capitania pelos pretos de Angola. Infelizmente, uma cópia da ordem transmitida ao governador não

3 Além do Brasil, o tribunal de Lisboa exercia jurisdição sobre todo o Atlântico luso, incluindo aí as ilhas dos Açores, Madeira, as colônias e feitorias africanas. O único tribunal do Santo Ofício instalado no ultramar português foi o de Goa, na Índia. Para se fazer presente na Colônia brasileira, a Inquisição lançou mão de várias estratégias, predominando no século XVIII a ação por meio da rede de agentes eclesiásticos (Comissários e notários) e civis, que eram os chamados familiares do Santo Ofício. As estruturas das dioceses também tiveram papel importante para viabilizar a presença inquisitorial nestas terras, não apenas na transmissão denúncias e processos para Portugal, mas também porque boa parte dos comissários eram membros dos cabidos e da justiça eclesiástica. 
foi anexada ao sumário.

\section{EQUILÍBRIOS DE PODER SUBJACENTES ÀS DENÚNCIAS}

A carta-denúncia enviada aos inquisidores expressa uma dinâmica conflituosa na administração colonial da capitania de Pernambuco. De um lado estavam os membros do clero (capuchinhos aliados com sacerdotes diocesanos) engajados em uma sanha punitivista contra os africanos e, de outro, o governador da capitania, José da Cunha e Menezes, o qual, segundo a denunciação, vinha adotando uma postura permissiva em relação às dinâmicas culturais africanas que destoava das administrações anteriores.

O padre Marques tece um panorama histórico acerca da postura adotada pelos governadores de Pernambuco diante das danças e batuques que considerava gentílicos, elencando nominalmente os representantes da coroa que não toleravam tais práticas. Em sua avaliação, foram exemplares na repressão os governos de Henrique Luiz (1737-1746), D. Marcos de Norona (1746-1749), Luiz Diogo Lobo (1756-1763) e Luís José da Cunha Grã Ataíde e Lencastro, Conde de Povolide (17681769). Em contraste com as administrações citadas, denunciava a soltura com que os "pretos de Angola" organizavam suas festas e cerimônias sob o governo de José César de Menezes, que ali estava desde 1774 e permaneceria até 1787. Os estudos que abordam o governo de Menezes centram-se principalmente nas questões ligadas ao funcionamento da Companhia Geral de Pernambuco e Bahia. Destacam como ele buscava equilibrar, de um lado, os interesses da Coroa em aprofundar o mercantilismo concebido pelo reformismo ilustrado da segunda metade do século XVIII e, de outro, a resistência das elites pernambucanas aos monopólios da companhia, que encareciam os cativos. ${ }^{4}$ No que toca às relações entre Menezes e as comunidades negras, Antonia Aparecia Quintão sugere que havia uma certa flexibilidade do governador quanto às tradições hierárquicas de origem africana construídas e reconstruídas pelos cativos no contexto colonial. Autorizava, por exemplo, a prática da expedição de patente de governador dos "pretos marcadores das caixas de açúcar" do porto, os quais ritualmente estariam subordinados ao rei do Congo eleito pela irmandade do Rosário. ${ }^{5}$

O clímax da tensão entre os dois pólos do poder colonial foi atingido quando os

4 Érica Dias, "Martinho de Melo e Castro e a extinção da companhia pombalina em Pernambuco", Anais do XXVI Simpósio Nacional de História - ANPUH, São Paulo, julho 2011, pp. 1-12.

5 Antonia Aparecida Quintão, Lá vem o meu parente: as irmandades de pretos e pardos no Rio de Janeiro e em Pernambuco (século XVIII), São Paulo: Anablume, FAPESP, 2002, pp. 180-182. 
capuchinhos, acompanhados de cinco clérigos seculares, saíram com uma cruz incitando a população a destruir os instrumentos empregados pelos negros em suas danças e batuques. Como resultado, "o povo, pelo dito dos missionários, quebraram e queimaram" os apetrechos. Essa medida repressiva afrontava diretamente a autoridade do governador Menezes, pois ele havia concedido "licença in scripts" que permitia os batuques. Afrontado pelos eclesiásticos, no dia seguinte mandou intimar os capuchinhos para que interrompessem seus excessos, "sob pena de os remeter para Lisboa". Além disso, condenou os cinco padres que os acompanhavam a uma pena de três mil réis cada. A multa serviria para a restituição dos instrumentos que haviam sido destruídos no ataque aos africanos, conforme relata o padre Domingos de Oliveira Marques:

condenou aos sinco sacerdotes seculares que os acompanharam em três mil reis cada um, para a refação de instrumentos quebrados por nao terem os Missionários com que pagar, de que se exaltaram os negros até com ditérios e cantigas subsanarem pelas ruas aos ditos Missionários (...).

O cruzamento das informações do sumário com fontes coevas diversas, sobretudo conjuntos documentais mais permeáveis ao cotidiano dos africanos e sua ação histórica, poderia sustentar análises sobre as estratégias e astúcias que os africanos adotaram para negociar aquelas margens de permissibilidade descritas nas denúncias. ${ }^{6}$

\section{PRÁTICAS RELIGIOSAS, SOCIAIS E CULTURAIS}

A obsessão dos inquisidores pelos detalhes das experiências religiosas dos réus na busca etnocêntrica de indícios de heresias resultou na descrição detalhada de uma série de práticas culturais desviantes em relação ao ideário da ortoxia da fé católica nos documentos preservados pelos arquivos do Santo Ofício. Como argumentou Ginzburg, o conhecimento do funcionamento dos tribunais, da estrutura dos processos e do contexto no qual os inquisidores atuavam permite o historiador transpor o filtro plasmado nos documentos e se aproximar do universo cultural e das crenças dos sujeitos por eles perseguidos. ${ }^{7}$

6 Lucilene Reginaldo identificou a adoção de estratégias de negociações pelos africanos de nação Angola presentes na Irmandade do Rosário em Salvador com vistas a obterem autorização para uso de "máscaras, danças no idioma de Angola com os instrumentos concernentes, cânticos e louvores". Lucilene Reginaldo, Os Rosários dos Angolas: irmandades negras, experiências escravas e identidades africanas na Bahia setecentista" (Tese de Doutorado, IFCHUNICAMP, 2005), p. 124.

7 Carlo Ginzburg, O inquisidor como antropólogo: uma analogia e as suas implicações. In: . A micro-história e outros ensaios, Rio de Janeiro: Bertrand, 1991, pp. 203-214. 
No caso brasileiro, João Reis, em seu estudo sobre a invasão de um terreiro de Calundu na vila de Cachoeira pelo aparato oficial da Bahia, no ano de 1785, sublinhou que os documentos da repressão, não apenas os da Inquisição, constituem a "fonte típica em que se inscreveu a história da religião afro no Brasil"8. Seguindo nesta trilha, desde finais da década de 1980 a historiografia vem explorando o espólio resultante das atividades repressivas da justiça eclesiástica e da Inquisição para empreender análises inovadoras acerca da multiplicidade das práticas religiosas coloniais de matriz africana em diferentes partes da América portuguesa. ${ }^{9}$

Nos anos 2000 e na década de 2010, a aproximação da historiografia sobre a cultura da população africana e seus descendentes no Brasil com a historiografia africanista resultou em uma importante inflexão nas suas escalas de análise. Seja por meio dos estudos enfocando povos específicos ou centrando em trajetórias individuais, notamos a constituição de um campo de pesquisa cada vez mais denso que lança mão das fontes inquisitorias para o estudo da diáspora africana. As ênfases recaem nas especificidades dos elementos africanos presentes nas minúcias descritas pelos notários a partir de uma perspectiva que conjuga as dinâmicas situadas nos dois lados do Atlântico, desvelando novas dimensões identitárias e religiosas que compunham o universo cultural dos povos escravizados e seus descendentes vivendo no Brasil. Podemos elencar como testemunhos dessa vertente o trabalho de James Sweet sobre os Cobu do interior do golfo do Benim $^{10}$, a análise de Vanicleia Santos sobre os equívos da associação entre o uso das bolsas de mandinga no mundo Atlântico e os povos Mandinga da África Ocidental ${ }^{11}$ e, mais recentemente, a tese de Alexandre Marcussi a respeito dos calundus em Minas gerais, privilegiando a trajetória de Luzia Pinta $^{12}$. Do lado Angolano, Roquinaldo Ferreira lançou mão de documentos do Santo Ofício para desvendar os intercâmbios culturais entre Angola e Brasil nos séculos XVIII e inícios do XIX, privilegiando a abordagem micro-biográfica. ${ }^{13}$

8 João Reis, "Magia Jeje na Bahia: a invasão do calundu do Pasto de Cachoeira, 1785, Revista Brasileira de História, v. 8, n. 16 , pp. $67-72,1988$, p. 60 .

9 Laura de Mello e Souza, O Diabo e a Terra de Santa Cruz: feitiçaria e religiosidade popular no Brasil colonial, São Paulo: Companhia das Letras, 1986; Luiz Mott, "Acotundá: raízes setecentistas do sincretismo religioso afrobrasileiro", Anais do Museu Paulista, nova série, volume XXXI, São Paulo, 1986, pp. 124-147, p. 138; Luiz Mott, Rosa Egipcíaca: Uma Santa Africana no Brasil, Rio de Janeiro, Bertrand Brasil, 1993; Luiz Mott, "O calundu Angola de Luzia Pinta: Sabará, 1739", Revista do IAC, Ouro Preto, UFOP, n. 01, 1994.

10 James Sweet, Domingos Alvares: African healing, and the intellectual history of the Atlantic world, Chapel Hill: University of North Carolina Press, 2011. Ver também, do mesmo autor, seu estudo anterior que centra no universo afro-português em perspectiva mais alargada: James Sweet, Recriar Africa: cultura, parentesco e religião no mundo afro-portugues (1441-1770), Lisboa: Edições 70, 2007.

11 SANTOS, Vanicléia Silva, "As bolsas de mandinga no espaço Atlântico: Século XVIII" (Tese de doutorado, FFLCH-USP, 2008).

12 Alexandre Marcussi, "Cativeiro e Cura: Experiências religiosas da escravidão atlântica nos calundus de Luzia Pinta, séculos XVII-XVIII" (Tese de doutorado, FFLCH-USP, 2015).

13 Roquinaldo Ferreira, Cross-Cultural Exchange in the Atlantic World. Angola and Brazil during the era of the slave 
O vigor desta historiografia abre caminhos para pensarmos nas potencialidades do documento "Sumário contra os Pretos de Angola" para o desenvolvimento de pesquisas centradas nas cosmologias e nas religiosidades dos povos oriundos da África Centro-Ocidental que foram traficados para para Pernambuco no Setecentos.

De maneira particular, a fonte em apreço oferece aportes para investigações tocantes aos ritos funerários e às suas relações com a ancestralidade no contexto da diáspora. Ao que tudo indica, as práticas fúnebres descritas no Sumário eram derivadas da cerimônia do tambo. Alexandre Marcussi, baseando-se na historiografia africanista e na obra de Antonio Cavazzi, define-a como uma complexa "cerimônia pela qual se produzia o antepassado, ou seja, pela qual um morto, inicialmente hostil, se convertia em ancestral, entendido como um ascendente com quem a linhagem mantinha uma relação positiva de lealdade e harmonia, e a quem podia - e devia - render culto regular." ${ }^{\prime 4}$ No reino de Matamba, o tambo durava oito dias, demandava uma hierarquia sacerdotal especializada e uma série de recursos materiais para as oferendas e envolvia possessão.

No episódio pernambucano, notamos a influência de aspectos da cultura colonial e portuguesa nas práticas culturais angolanas, o que nos alerta para a impossibilidade de essencializar a análise das tradições africanas no Brasil. Os tambos parecem congregar elementos do catolicismo, aparentemente incluindo a celebração de missas na relação com o mundo dos ancestrais e não duravam oito dias como em Angola, sendo encurtados para caber no ritmo e calendário do regime de trabalho da escravidão. Neste estudo introdutório trabalhamos com a hipótese de que os elementos católicos foram incorporados às tradições africanas em termos africanos, e não o contrário. Ou seja, foram lidos e apropriados seletivamente com base nas cosmologias africanas que organizavam a vida social e a relação com o mundo invisível. Os trabalhos sobre a África Centroocidental convergem no sentido de apontar a complexidade do processo de penetração do catolicismo nas cosmologias africanas, sobretudo a cosmologia Bakongo, emergindo daí um catolicismo africano. ${ }^{15}$ Linda Heywood e John Thornton argumentam que estas transformações culturais tinham início no próprio continente africano em razão da conversão do reino do Congo no

trade, Cambridge: Cambridge University Press, 2012. Sobre a repressão aos entambes em Angola na segunda metade do século XVIII, consultar: Lucilene Reginaldo, "Os Rosários dos Angolas”, p. 33.

14 Alexandre Marcussi, "Cativeiro e cura”, p. 105. Ver, sobretudo as páginas 103-106.

15 Wyatt Macgaffey, Religion and society in central Africa : the BaKongo of lower Zaire, Chicago: University of Chicago Press, 1986; John Thornton, "The Development of an African Catholic Church in the Kingdom of Kongo, 1491-1750." The Journal of African History, 25 (2), 1984, pp. 147-167; Cécile Fromont, The art of conversion : Christian visual culture in the Kingdom of Kongo, Williamsburg: University of North Carolina Press, 2014; Marina de Mello e Souza, Além do visível: poder, catolicismo e no Congo e em Angola (séculos XVI e XVII), São Paulo: EDUSP, 2018. 
século XVI e da penetração portuguesa no território que constitui posteriomente Angola. Tratava-se de um processo de transformações culturais e formação de culturas crioulas que impactava tanto os portugueses, que iam se "africanizando", e os africanos; muitos daqueles traficados para as Américas já possuíam variados graus de conhecimento do catolicismo e da língua portuguesa. ${ }^{16}$

O Sumário detalha também a dimensão material dos cultos, revelando os instrumentos musicais e sonoros empregados nos ritos funerários, como atabaques, marimbas e outros. Descreve suas formas, material de que eram feitos e sons que emitiam. Tudo se passava em torno de uma "meza coberta com uma baeta preta".

O movimento dos corpos ("estrépidos de pés e mãos") dos participantes dos rituais e os versos cantados em português ("ditos blasfêmicos como Oh meu Deus, ora vamos para o Céu) ou nas línguas africanas ("cantinelas na sua língua gentílica") não escapam aos olhos e aos ouvidos dos clérigos portugueses.

Os denunciantes reprovam enfaticamente a convivência entre homens e mulheres no âmbito dos rituais que envolviam danças por conta da sensualidade que enxergavam ali: "batuque entre homens e mulheres que consiste em representar um ato torpe de fornicação, acompanhada de instrumentos, estrépidos de pés e mãos, com ditos desonestos e, para maior desgraça nos tempos presentes, com ditos blasfêmicos como Oh meu Deus, ora vamos para o Céu". Em outro trecho: "ajuntam umas e outros de diverso sexo e à roda da mesa fazem uma dança ao modo de sua terra".

\section{DEMONIZAÇÃO DAS RELIGIOSIDADES AFRICANAS E DESTRUIÇÃO DE SEUS OBJETOS DE CULTO}

O uso de expressões depreciativas pelos oficiais eclesiásticos para descrever as cerimônias religiosas dos escravizados de nação Angola, associando-as ao inferno, e a destruição de seus instrumentos musicais são episódios do longo processo histórico de demonização das religiões africanas. ${ }^{17}$ Tal processo não se restringia ao espaço colonial brasileiro. A historiografia africanista demonstra que, na verdade, este fenômeno esteve articulado também à penetração dos missionários e outros agentes eclesiásticos do outro lado do Atlântico. A ação e os projetos de missionação eram marcados pela circulação de seus agentes por todo o ultramar e pela troca intensa de

16 Linda Heywood; John Thornton, Central Africans and cultural transformations in the American diaspora, Cambridge ; New York: Cambridge University Press, 2001.

17 Laura de Mello e Souza, Inferno Atlântico: Demonologia e Colonização (Séculos XVI-XVIII), São Paulo: Companhia das Letras, 1993. 
correspondências e experiências que mediavam a ação missionária. Na África Ocidental, segundo Nicolau Pares, os primeiros registros indiretos deste processo aparecem no século XVII, evidenciando a associação e sincretismo entre a figura do demônio cristão e o vodu Legba (Elegbaral Elégbára), do panteão Fon, e o orixá Exu (Esù), do panteão Yorubá. ${ }^{18}$ No contexto da África Centroocidental, o processo ocorreu de forma menos precisa e foi caracterizado pela maior penetração no interior do continente por um largo período de tempo. ${ }^{19}$ Anne Hilton ${ }^{20}$, John Thornton ${ }^{21}$, Marina de Mello e Souza ${ }^{22}$, Alexandre Marcussi ${ }^{23}$, entre outros historiadores que trabalharam com a documentação e crônicas produzidas pelos missionários, relatam diversas circunstâncias em que os agentes europeus associavam o diabo cristão às atividades dos sacerdotes ngangas e xinguilas. Eram acusados de invocar o demônio ao manejar, na linguagem missionária, os fetiches minksi (Kikongo) e Kiteke (Kimbundu) para manipular as forças do mundo invisível.

A ordem missionária que esteve por trás da destruição dos atabaques e marimbas em Pernambuco teve membros envolvidos também em ataques e queima de altares do outro lado do Atlântico durante o século XVIII. Tais ofensivas dos capuchinhos foram registradas nos documentos da administração colonial, nos relatos dos missionários e na iconografia católica, conforme figura abaixo, reproduzida por Suely Almeida. Estudando a ofensiva da administração portuguesa contra os entambes e outras cerimônias consideradas gentílicas, a autora conclui que "Queimar e demolir casas e palhoças, além de prender, condenar e executar adoradores foi um método recorrente imposto pelas autoridades reinóis no enclave angolano.". ${ }^{24}$

A demonização das práticas religiosas africanas, que o documento aqui publicado permite reconstituir, inseria-se, portanto, num conjunto mais amplo de estratégias violentas empregadas pelos europeus na construção dos impérios coloniais no espaço atlântico. A detração do universo cultural da população africana estava intimamente relacionada à exploração da sua força de trabalho e à inferiorização de seus lugares nas hierarquias sociais. Nos século XIX e XX, o processo passou a ser operado pelas forças policiais e foi um elemento importante da racialização das relações

18 Nicolau Pares, O pai, o rei e a morte: a religião Vodum na antiga Costa dos Escravos na África Ocidental, São Paulo: Companhia das Letras, 2017, p. 112.

19 Nicolau Pares, O pai, o rei e a morte.

20 Anne Hilton, The kingdom of Kongo, Oxford: Oxford University Press, 1985, p. 195.

21 John Thornton, A África e os africanos na formação do mundo Atlântico 1400-1800, Rio de Janeiro: Elsevier, 2004, pp. 326-327

22 Alexandre Marcussi, Cativeiro e Cura, pp. 33-34.

23 Marina de Mello e Souza, Além do visível: poder, catolicismo e no Congo e em Angola (séculos XVI e XVII), São Paulo: EDUSP, 2018, pp. 249-261.

24 Suely Almeida, "Catolicismo, Gentilismo e Mestiçagem na África Ocidental e Centro Ocidental no século XVIII", Revista de Estudos de Teologia e Ciências da Religião, v. 14, 2016, pp. 240-261, p. 622. 
sociais brasileiras. Em boa medida, era isso que legitimava a apreensão e destruição de objetos litúrgicos do Candomblé. 25

\section{MALUNGOS E PARENTES}

Um aspecto do Sumário que chama bastante atenção é o fato da denúncia ser contra os africanos de Angola em sua coletividade: "contra os pretos de Angola do continente de Pernambuco". Acreditamos que essa tendência a homogeneizar os cativos daquela origem expressava a face externa de uma comunidade formada em Pernambuco por pessoas que compartilhavam, além do trauma da diáspora, elementos de um mesmo complexo cultural centroafricano $^{26}$. E o vocábulo Malungo, como será explorado abaixo, era o que codificava os elos entre os membros daquela comunidade.

No século XVIII, a nação Angola designava, basicamente, os escravizados de origens múltiplas que eram embarcados no porto de Luanda. O próprio documento registrou em dois momentos que os pretos denunciados eram "do gentio de Angola e outros distritos", "negros do gentio de Angola, especialmente os do Gentio da Costa". Ou seja, havia diversas origens encobertas pelo termo abrangente "Angola".

De acordo com Joseph Miller, os luso-brasileiros, em 1570, definiam Angola como a "região ngola a kiluanje, sob o domínio de governantes africanos ao longo do meio do rio Cuanza." ${ }^{27}$ Posteriormente, "os representantes governamentais estabeleceram seu principal porto de escravatura em Luanda, no começo do século XVII, eles designaram as regiões interiores sujeitas ao seu controle militar como o 'Reino e conquista d'Angola." ${ }^{28}$ Assim, "“Angola' a partir de então,

25 João José Reis, Domingos Sodré, um sacerdote africano: escravidão, liberdade e candomblé na Bahia do século XIX, São Paulo: Companhia das Letras, 2008; Nicolau Pares, A formação do candomblé : história e ritual da nação jeje na Bahia, Campinas: Editora Unicamp, 2006.

26 Em sua análise sobre a constituição de Palmares no século XVII, Sílvia Lara destacou a importância de considerarmos as culturas políticas centro-africanas subjacentes à constituição da rede dos mocambos e da comunidade ali formada. O fato de os escravos de Pernambuco seiscentista serem majoritariamente oriundos da macro região Congo/ Angola forneceu-lhes, em suas palavras, uma gramática política comum. LARA SH. Palmares \& Cucaú: o aprendizado da dominação. Campinas: IFCH, 2008. (Tese apresentada para o concurso de Professor Titular Área de História do Brasil). Campinas: Universidade Estadual de Campinas, 2008.

27 Joseph Miller, “África Central durante a era do comércio de escravizados, de 1490 a 1850", in Linda Heywood (org.), Diáspora negra no Brasil, São Paulo: Contexto, 2010, pp. 38-42, p. 38

28 Joseph Miller, “África Central durante a era do comércio de escravizados, de 1490 a 1850", p. 42. Diferentemente do uso feito pelos luso-brasileiros, os europeus do Norte empregavam o termo Angola para designar a origem dos cativos vindos de todo o território ao sul do Cabo Lopes. 
serviu no Brasil como termo cognato para Luanda" ${ }^{29}$. Segundo Lucilene Reginaldo, no contexto colonial, a nação Angola, que designava a origem dos escravizados deportados via Luanda, "era bastante genérica e imprecisa, tanto em termos étnicos como de procedência geográfica ou regional mais específica". ${ }^{30}$

O leque de trabalhos que se debruçou sobre as rotas do tráfico entre Pernambuco e a África no século XVIII destaca a importância que o porto de Luanda desempenhava no abastecimento da praça recifense. E o estabelecimento da Companhia Geral de Pernambuco e Paraíba em 1759 certamente acentuou a prevalência angolana no tráfico com Pernambuco. A Coroa, entre outras motivações para a criação da companhia monopolista, pretendia diminuir a presença pernambucana na Costa da Mina, onde tinha menos meios para taxar e controlar o comércio de cativos, pois ali os portos eram dominados pelas elites africanas. ${ }^{31}$ Os dados sistematizados por Suely Almeida e Jéssica Sousa demonstram a prevalência angolana em Pernambuco tanto no número de embarcações como no número de pessoas desembarcadas.

\section{Quadro 1}

\section{Número de embarcações que vieram da Costa Africana para o porto de Recife}

\begin{tabular}{|c|c|c|}
\hline Período & $\begin{array}{c}\mathrm{N}^{\mathrm{o}} \text { de embarcações vindas } \\
\text { de Angola }\end{array}$ & $\begin{array}{c}\mathrm{N}^{\mathrm{o}} \text { de embarcações vindas } \\
\text { da Costa da Mina }\end{array}$ \\
\hline $1742-1759$ & 121 & 63 \\
\hline
\end{tabular}

29 Joseph Miller, “África Central durante a era do comércio de escravizados, de 1490 a 1850”, p. 42. Durante muito tempo, pensou-se que os escravizados da África Centro-ocidental, de acordo com o avançar do tráfico, eram oriundos cada vez mais do interior-oeste, visto que as lógicas de escravização africana tinham sempre como alvo outsiders, pessoas desprovidas dos direitos e deveres estabelecidos pelas lógicas de pertencimento às linhagens. Desta forma, haveria sempre uma fronteira da escravização se movento junto com a penetração territorial europeia no continente, como argumentou Joseph Miller: Joseph Miller, Way of death merchant capitalism and the Angolan slave trade, 1730-1830, Madison: University of Wisconsin Press, 1988. Mais recentemente, historiadores brasileiros tem relativizado esta tese da slaving frontier em relação ao fim do século XVIII e início do XIX. Mariana Candido, estudando a região de Benguela, argumentou que a pressão atlântica foi se intensificando de tal maneira que alcançou um efeito tão desruptivo nas sociedades africanas a ponto de engolfar nas redes do tráfico pessoas livres que viviam próximas ao litoral, inclusive gente que já estava em contato com a língua e cultura portuguesa. Cf. Mariana Candido, An african slaving port and the Atlantic world: Benguela and its hinterland. New York: Cambridge University Press, 2013. Daniel Domingues da Silva, com base em dados da comissão mista BrasilInglaterra e em documentos angolanos, demonstrou que a maioria dos escravizados centro-ocidentais, entre $1831 \mathrm{e}$ 1855, era, na verdade, oriunda de uma estreita faixa litorânea. Portanto, os capturados tendiam a ser oriundos de sociedades próximas às de seus captores. Cf.: Daniel Domingues da Silva, The Atlantic Slave Trade from West Central Africa, 1780-1867, Cambridge: Cambridge University Press, 2017.

30 Lucilene Reginaldo, “Os Rosários dos Angolas”, p. 185.

31 Maximiliano Menz, "A Companhia de Pernambuco e Paraíba e o funcionamento do tráfico de escravos em Angola (1759-1775/80)", Afro-Ásia (UFBA), v. 48, 2013, Pp. 45-76; Carlos da Silva Jr., "Interações atlânticas entre Salvador e Porto Novo (Costa da Mina) no século XVIII", Revista de História (USP), São Paulo, n. 176, pp. 1-41, 2017. 


\begin{tabular}{|c|c|c|}
\hline $1759-1777$ & 78 & 25 \\
\hline
\end{tabular}

Fonte: Suely Almeida; Jéssica Sousa, "O Comércio das Almas: as rotas entre Pernambuco e Costa da África 1774-1787", Revista Ultramares, v. 1, 2013, pp. 34-53, p. 44.

\section{Quadro 2}

\section{Número de escravos desembarcados no porto de Recife}

\begin{tabular}{|l|l|l|}
\hline Período & Angola & $\begin{array}{l}\text { Costa da } \\
\text { Mina }\end{array}$ \\
\hline $1742-1759$ & 38.383 & 16.189 \\
\hline $1759-1777$ & 29.733 & 7.801 \\
\hline
\end{tabular}

Fonte: Suely Almeida; Jéssica Sousa, "O Comércio das Almas: as rotas entre Pernambuco e Costa da África 1774-1787", Revista Ultramares, v. 1, 2013, pp. 34-53, p. 44.

É importante notar que Pernambuco nunca deixou de importar pessoas escravizadas dos diversos portos da Costa da Mina, como pudemos observar nos dados reproduzidos acima e também por meio das evidências presentes no trabalho de Gustavo Acioli para o período que vai 1654 a $1760 .^{32}$

Como vimos, a denúncia refere-se aos governadores anteriores da capitania, informando que, em sua maioria, eram duros na proibição às práticas culturais africanas. Embora devamos cogitar que este pudesse ser um artifício retórico dos oficiais eclesiásticos para atacar o governador Meneses, é muito provável que os batuques promovidos pelos cativos constituiam uma tradição que vinha de longa data, recuando aos primórdios da escravidão africana e presença angolana na região.

Ao descrever os ritos fúnebres para os inquisidores, o comissário Manoel Félix da Cruz especificou que eram praticados pelos "negros do Gentio de Angola, especialmente os do Gentio da Costa" quando "morre algum seu parente ${ }^{33}$, ou malungo". Então costumavam por "publicamente nas

32 LOPES, Gustavo Acioli, "Negócio da Costa da Mina e o Comércio Atlântico: tabaco, açúcar, ouro e tráfico de escravos: Pernambuco (1654-1760)" (Tese de doutorado, FFLCH-USP, 2008).

33 Os temos Malungo e Parente aparecem no documento de forma sobreposta, como se fossem quase sinônimos. Tanto João Reis, em sua análise para o século XIX, como Aparecida Quintão, em seu estudo sobre o século XVIII, indicam que o termo parente possuía o sentido de "parente de nação", expressava a relação entre as pessoas que tinham a mesma origem étnica, sobretudo no contexto das irmandades católicas negras. Muitas destas associações 
praças, e outros lugares uma mesa coberta com uma baêta ${ }^{34}$ preta a pedirem esmola para mandar dizer missas por alma do tal parente, ou malungo, que faleceu". Nestas ocasiões "se ajuntam umas e outros de diverso sexo e a roda da mesa fazem uma dança ao modo de sua terra com umas tabaques e outros instrumentos funebres".

A desenvoltura demonstrada pelos oficiais eclesiásticos no emprego do vocábulo Malungo para se referir aos vínculos de amizade e companheirismo nutridos pelos africanos de Angola nos leva a pensar que seu uso pelas comunidades escravizadas vinha de tempos bem mais recuados. Era corrente entre eles, foi ganhando densidade e ultrapassando o universo social dos cativos até que passou a ser usado correntemente em Pernambuco. Por isso já fazia parte do léxico das autoridades portuguesas no século XVIII, chegando até Lisboa.

Manoel Félix da Cruz, o comissário da Inquisição que transmitiu a denúncia ao Santo Ofício, era membro de uma família enraizada em Pernambuco havia várias gerações, pelo menos pelo lado materno. Seu processo de habilitação para se tornar agente inquisitorial informa que ele havia nascido na freguesia da Vargem em 1720, filho Manoel Marques da Cruz. ${ }^{35}$ Portanto, havia crescido entre uma população que convivia com os "pretos de Angola" havia muitos anos.

Indo aos sermões do padre Vieira pregados nas irmandades do Rosário dos engenhos da Bahia, notamos que, na verdade, a palavra Malungo já era falada na América portuguesa desde o século XVII. Ela aparece no sermão XX, publicado em 1688, em que o inaciano repreendia a atitude da classe proprietária por não querer celebrar a festa do Rosário no mesmo domingo que os pretos. Vieira forjou uma imagem contrastando a união que havia entre os africanos e a desunião que grassava entre os brancos:

Dos pretos é tão própria e natural a união que a todos os que tem a mesma cor, chamam parentes; a todos os que servem na mesma casa, chamam parceiros; e a todos os que se embarcam no mesmo navio, chamam malungos. E os brancos? Não basta andarem nove meses juntos no mesmo ventre, como Jacó e Esaú, para se não aborrecerem; nem basta serem filhos fo mesmo pai e da mesma mãe, como Caim e Abel, para se não matarem. ${ }^{36}$

caritativas eram organizadas a partir das "nações" dos cativos. Cf. João Reis, A Morte é uma festa: ritos fúnebres e revolta popular no Brasil do século XIX, São Paulo: Companhia das Letras, 1991, p. 55; Antonia Aparecida Quintão, Lá vem o meu parente, pp. 90-99. Portanto, malungo tendia a expressar não apenas os vínculos entre companheiros de um mesmo barco, mas também a relação entre africanos que tinham a mesma origem.

34 Segundo Raphael Bluteau, baeta significa "pano de lã". Vol. 2. http://dicionarios.bbm.usp.br/pt-br/dicionario/1/baeta

35 Arquivo Nacional da Torre do Tombo, Habilitações do Santo Ofício, maço 176, documento 1868. 1760.

36 Padre Antonio Vieira, Maria Rosa Mística. Sermão XX. Parte II. Lisboa: Impressão Craesbeeckiana, 1688. P. 165. Negrito nosso.

Sou grato a Robert Slenes, colega e amigo, pela generosa indicação desta referência. 
Vieira sentiu a necessidade de esclarecer a definição do vocábulo malungo usado entre os escravizados: chamavam assim "os que se embarcam no mesmo navio". Na segunda metade do século XVIII, como vimos no Sumário, o termo já era empregado pelos agentes do poder colonial sem precisar recorrer à sua definição, pressupunham que qualquer pessoa compreenderia seu significado. Além disso, o Sumário fornece evidências de que a comunidade de malungos se organizava a partir de elementos que precediam a experiência de estarem juntos no mesmo navio, conforme veremos mais adiante.

Os estudos sobre o mundo afro-atlântico há tempos vem sublinhando a importância dos elos construídos pelos africanos nos navios negreiros como forma de resistir à experiência dolorosa da viagem transatlântica. No ensaio "O nascimento da Cultura afro-americana”, Sidney Mintz e Richard Price argumentam que os laços formados durante a traumática travessia por pessoas de grupos étnicos variados eram as primeiras fagulhas da formação da cultura afro-americana. Na visão dos autores, as embacações eram carregadas com uma imensa diversidade de povos cujas línguas não eram mutuamente compreensíveis. Em várias regiões do Caribe, os laços tecidos na travessia depois continuavam sendo estreitados na constituição de culturas crioulas que englobavam nestas redes de solidariedade os descendentes dos africanos nascidos no cativeiro. ${ }^{37}$

As expressões que codificavam os vínculos criados na travessia variavam de acordo com as regiões escravistas: sibbi ou sippi no Suriname; malongue em Trinidad; bâtiment no Haiti; shipmate na Virgínia, Barbados e Jamaica; nesta última, shipmate era, inclusive, sinônimo de irmão nas comunidades escravizadas e poderia chegar ao ponto de interditar relações sexuais entre seus membros. ${ }^{38}$ Em partes do Caribe, segundo Marcus Rediker, "mais tarde, os escravos que tinham viajado juntos estendiam ainda mais esse 'parentesco', recomendando aos filhos que chamassem seus companheiros de bordo de 'tio' e 'tia'. ${ }^{39}$

No caso específico do Brasil, Robert Slenes realizou análise detida sobre a formação de identidades sociais e culturais no âmbito da diáspora dos povos da África Centro-ocidental para as

37 Sidney Mintz; Richard Price, O nascimento da cultura afro-americana : uma perspectiva antropológica, Rio de Janeiro: Pallas, 2003.

38 Sidney Mintz; Richard Price, O nascimento da cultura afro-americana, pp. 65-67. Marcus Rediker, O navio negreiro: uma história humana, São Paulo: Companhia das Letras, 2011, pp. 310-312.

39 Marcus Rediker, O navio negreiro: uma história humana, pp. 310-312. Apesar de destacar a formação de laços de companheirismo nas embarcações, o autor demonstra que o navio negreiro era um universo bastante complexo. Cita vários exemplos de rivalidades étnicas trazidas da África Ocidental, onde havia uma grande variedade formações políticas e linguísticas, que se desdobravam em conflitos violentos nas embarcações. Nesse sentido, como estratégia de controle social, os tripulantes contavam com a ajuda de intérpretes para evitar acorrentar juntos cativos de "nações" diferentes. Sobre este aspecto, ver as páginas 279-280. 
áreas rurais do sudeste brasileiro do Oitocentos. Apoiado na linguística histórica e na demografia da escravidão e do tráfico, argumentou que os africanos oriundos das áreas falantes de Kikongo, Kimbundu e Umbundu, que constituíam a esmagadora maioria das comunidades escravas da região enfocada em seu estudo, compartilhavam códigos culturais e suas línguas, por serem todas do tronco linguístico bantu, eram mutuamente compreensíveis. Por isso, Malungo, que tinha ressonância nas três línguas, originalmente significava barco e foi passando também a significar companheiro de barco, contendo em si a dimensão traumática da travessia. ${ }^{40}$ Mais do que a experiência comum da travessia, tratava-se da emergência de laços e identidades possibilitados pelo fato de que eram originários da macro-área centro-africana, em que, apesar de especificidades, é possível encontrar um amplo complexo cultural formado pelos povos falantes das línguas do tronco Bantu. Os elementos culturais comuns desta região emergiram na travessia terrestre, Atlântica, e depois na experiência do cativeiro. Assim, de acordo com o autor, "A palavra 'encapsula' o processo pelo qual escravos, falantes de línguas bantu diferentes e provindos de diversas etnias, começaram a descobrir-se como 'irmãos'."41 Do ponto de vista social e político, a língua e os aspectos culturais comuns que partilhavam permitiram a construção de uma comunidade que desenvolveu múltiplas estratégias de resistência escrava. Estas tornaram-se um problema político para o processo de formação do estado-nação, que tinha que enfrentar a pressão inglesa pela abolição na face internacional e a pressão das senzalas, no contexto interno. Portanto, o termo Malungo expressava os elos entre os membros das comunidades formadas por pessoas que constituíram esse mundo.

Para a Bahia de inícios do século XIX, Lucilene Reginaldo encontrou o termo Malungo sendo aplicado para designar vínculos entre companheiros que falavam Kicongo (da nação Congo) em um inquérito de 1807 aberto em Santo Amaro para apurar uma denúncia de contrabando de pólvora. Ao que parece, portanto, Malungo poderia ser utilizado para traduzir as conexões entre

40 "Seja como for, mesmo que malungu, no sentido de 'companheiros (do sofrimento)', tivesse uma origem independente não pode haver dúvida de que falantes de kimbundu e umbunto, junto com os de kikongo, teriam chegado a 'malungo' - 'companheiro da mesma embarcação' -, pelo menos em parte através do conceito compartilhado de 'meu barco'." Robert Slenes, "Malungu, ngoma vem!: Africa coberta e descoberta do Brasil", Revista de História da USP, 1992 (12):48, p. 53.

41 Robert Slenes, "Malungo Ngoma Vem", p. 54. A análise do autor parte da definição que o dicionário Morais e Silva de 1789 deu ao termo malungo. Em 2018 o autor voltou ao tema, expandindo seu argumento privilegiando as metáforas conceituais dos complexos culturais da África Centro-ocidental. Defende que os impulsos iniciais que levaram à criação de conexões no navio negreiro antecediam a travessia atlântica, visto que compartilhavam visões de mundo expressas em metáforas comuns. Cf. Robert Slenes, "Metaphors to live by in the Diaspora: conceptual tropes and ontological wordplay among Central Africans in the Middle Passage and beyond", In: Ericka Abaugh, Luna Rathvyn (Orgs.), Tracing language movement in Africa. New York: Oxford University Press, 2018, pp. 343364. 
cativos de uma mesma nação. Conforme transcrição da autora, o escrivão registrou que o denunciante Manoel Uzeda Rodrigues da Silva ficara sabendo da ocorrência envolvendo o desvio de pólvora por meio de João "malungo do escravo do denunciante e de igual nação". ${ }^{42}$

Mais recentemente, Alex Borucki identificou a formação de identidades sociais entre os africanos e seus descendentes na região do Rio da Prata (Argentina, Uruguai e Paraguai) entre o fim do período colonial e as primeiras décadas após a independência. Por exemplo, alguns casais relataram em seus processos matrimoniais terem se conhecido nas embarcações negreiras. A experiência comum compartilhada nas travessias terrestre e atlântica, nas irmandades católicas, nos batalhões e em outros espaços resultaram na formação da cultura negra platense, que transpunha as fronteiras dos estados-nações ali em construção. ${ }^{43}$

Em Pernambuco, o documento aqui publicado possibilita análises acerca das dinâmicas de formação de comunidades de Malungos em um contexto onde os povos de origem Bantu, embora fossem a maioria dos traficados, conviviam com grupos oriundos da Costa da Mina. Os dados do tráfico, compilados por Suely Almeida e Jessica Sousa ${ }^{44}$, Gustavo Acioli e Maximiliano Menz ${ }^{45}$, e os registros paroquiais, trabalhados por Gian Carlo $^{46}$, evidenciam a persistência da presença dos povos da África Ocidental (nação Mina) em Pernambuco do século XVIII e inícios do XIX.

Em síntese, considerando os estudos de Slenes para o sudeste bantu, as evidências presentes no trabalho de Lucilene Reginaldo e o uso do termo Malungo em Pernambuco, podemos concluir que, tendencialmente, a palavra Malungo abrangia os membros das comunidades formadas por falantes das línguas do tronco bantu: Kikongo, Umbundu e, sobretudo, Kimbundu (falado nos territórios habitados pelos vários grupos Ambundos, incluindo o reino do Ndongo, onde se situa a atual Angola). Mais do que apenas companheiros de barco, a palavra estava relacionada a um conjunto mais amplo de práticas sociais, religiosas e culturais de povos que compartilhavam um

42 Reginaldo, "Os Rosários dos Angolas", p. 189. A transcrição do trecho do processo aqui reproduzida foi realizada pela autora a partir do processo presente Arquivo Público do Estado da Bahia, Maço 408, Capitães Mores - Santo Amaro, Junho/1807.

43 Alex Borucki, From Shipmates to Soldiers. Emerging Black Identities in the Rio de la Plata, Albuquerque: University of New Mexico Press, 2015.

44 Suely Almeida; Jéssica Sousa, "O Comércio das Almas: as rotas entre Pernambuco e Costa da África - 1774-1787", Revista Ultramares, v. 1, 2013, pp. 34-53.

45 Gustavo Acioli, Maximilano Menz, "Resgate e Mercadorias: uma análise comparada do tráfico luso-brasileiro de escravos em Angola e na Costa da Mina (Século XVIII)", Afro-Asia (UFBA), v. 37, 2008, pp. 43-72; Ver também: Gustavo Acioli, "Negócio da Costa da Mina e o Comércio Atlântico: tabaco, açúcar, ouro e tráfico de escravos: Pernambuco (1654-1760)" (Tese de doutorado, FFLCH-USP, 2008).

46 Gian Silva, "A presença de Africanos em Pernambuco: aspectos sobre escravidão, família e sociedade no período colonial, séculos XVI ao XIX", Revista Ultramares, v. 1, 2013, pp. 10-33. 
fundo cultural cujos aspectos comuns emergiram na diáspora, sobrepondo-se aos contrastes que eram salientes no continente africano. O uso de Malungo para se referir de forma particular aos escravizados de nação Angola num contexto em que conviviam com os de nação Mina, embora estes tivessem um peso demográfico bem menor, reforça a importância da densidade dos laços entre os povos de origem bantu na diáspora. Portanto, a palavra em português que designava companheiro de barco não foi forjada na Torre de Babel linguística imaginada por Mintz e Price, visto que Kikongo, Kimbundu e Umbundu, apesar de guardarem variações importantes, são idiomas mutuamente compreensíveis. Mais do que uma questão linguística, a experiência comunitária após a travessia demonstra o sentido afro-cêntrico dos ritos e cerimônias fúnebres em Pernambuco. Malungo aparece no Sumário sendo empregada para designar os membros de uma comunidade que se reunia para a realização de práticas fúnebres conhecidas como Tambo. O micro-cosmo social do navio negreiro foi certamente um lócus importante destas experiências, mas os princípios organizadores das comunidades africanas na diáspora remontavam ao continente africano.

O fato de o léxico Malungo ser aplicado para conceitualizar os laços entre membros de comunidades formadas por povos da Africa centro-ocidental não significa que os africanos oriundos da África Ocidental (sobretudo portos da baía do Benim) deixassem de forjar identidades a partir da experiência comum da travessia terrestre e, posteriormente, atlântica. Estudando as trajetórias de um grupo de pessoas que foram trazidas de Lagos para o Rio de Janeiro em 1821 (após serem resgatados pela comissão mista anglo-portuguesa), Walter Hawthorne argumenta que parte daqueles cativos, Nagôs (71\%) em sua maioria, construíram uma comunidade no Rio a partir das ligações que tinham estabelecido no navio negreiro que os havia transportado. Tais laços emergiram nas petições de liberdade que apresentaram às autoridades após passarem 14 anos trabalhando de maneira coercitiva sob o estatuto de aprendizes emancipados. ${ }^{47}$ Ao que parece, no entanto, não havia no país um termo em Yorubá cujo uso e difusão se comparasse ao do vocábulo bantu Malungo, que acabou sendo incorporado no português brasileiro e utilizado em documentos oficiais.

Em suma, a publicação do "Sumário contras os pretos de Angola" abre possibilidades para a compreensão de novas dimensões relacionadas à emergência da palavra "malungo" e das dinâmicas específicas que ela encapsulava. Aponta a importância de considerarmos experiências que tiveram lugar nas capitanias mais antigas do Brasil ainda no período colonial para ampliarmos o quadro já

47 Walter Hawthorne, "Being Now, as It Were, One Family:" Shipmate Bonding on the Slave Vessel Emilia, in Rio de Janeiro and throughout the Atlantic World, Luso-Brazilian Review, 45 (1), 2008, pp. 53-77. 
bem identificado de o uso do vocábulo Malguno no sudeste rural do século XIX.

As várias camadas de significados sociais e culturais plasmadas no termo Malungo poderão ser melhor compreendidos com o apoio da historiografia que se debruçou sobre outros espaços de sociabilidade africanas em Pernambuco colonial, como as irmandades, por exemplo; e com o apoio de estudos acerca das origens das escravarias e suas formas de interação e constituição de laços de parentesco consanguíneo e fíctício. São estas potencialidades que justificam a transcrição e a publicação do "Sumário contra os pretos de Angola do continente de Pernambuco".

\section{REFERÊNCIAS BIBLIOGRÁFICAS}

ACIOLI, Gustavo; MENZ, Maximilano. "Resgate e Mercadorias: uma análise comparada do tráfico luso-brasileiro de escravos em Angola e na Costa da Mina (Século XVIII)", Afro-Asia (UFBA), v. 37, 2008, pp. 43-72;

ALMEIDA, Suely; SOUSA, Jéssica. "O Comércio das Almas: as rotas entre Pernambuco e Costa da África - 17741787", Revista Ultramares, v. 1, 2013, pp. 34-53.

ALMEIDA, Suely. "Catolicismo, Gentilismo e Mestiçagem na África Ocidental e Centro Ocidental no século XVIII", Revista de Estudos de Teologia e Ciências da Religião, v. 14, 2016, pp. 240261.

BORUCKI, Alex. From Shipmates to Soldiers. Emerging Black Identities in the Rio de la Plata. Albuquerque: University of New Mexico Press, 2015.

CANDIDO, Mariana. An african slaving port and the Atlantic world: Benguela and its hinterland. New York: Cambridge University Press, 2013.

DIAS, Érica. "Martinho de Melo e Castro e a extinção da companhia pombalina em Pernambuco", Anais do XXVI Simpósio Nacional de História - ANPUH, São Paulo, julho 2011, pp. 1-12.

FERREIRA, Roquinaldo. Cross-Cultural Exchange in the Atlantic World. Angola and Brazil during the era of the slave trade. Cambridge: Cambridge University Press, 2012.

FROMONT, Cécile. The art of conversion : Christian visual culture in the Kingdom of Kongo. Williamsburg: University of North Carolina Press, 2014.

GINZBURG, Carlo. O inquisidor como antropólogo: uma analogia e as suas implicações. In: . A micro-história e outros ensaios. Rio de Janeiro: Bertrand, 1991, pp. 203-214.

HAWTHORNE, Walter "Being Now, as It Were, One Family:" Shipmate Bonding on the Slave Vessel Emilia, in Rio de Janeiro and throughout the Atlantic World, Luso-Brazilian Review, 45 (1), 2008, pp. 53-77.

HEYWOOD, Linda; THORNTON, John. Central Africans and cultural transformations in the American diaspora. Cambridge ; New York: Cambridge University Press, 2001.

HILTON, Anne. The kingdom of Kongo. Oxford: Oxford University Press, 1985.

LARA, Silvia. Palmares \& Cucaú: o aprendizado da dominação. Campinas: IFCH, 2008. (Tese apresentada para o concurso de Professor Titular Área de História do Brasil). Campinas: Universidade Estadual de Campinas, 2008. 
LOPES, Gustavo Acioli. "Negócio da Costa da Mina e o Comércio Atlântico: tabaco, açúcar, ouro e tráfico de escravos: Pernambuco (1654-1760)" (Tese de doutorado, FFLCH-USP, 2008).

MACGAFFEY, Wyatt. Religion and society in central Africa : the BaKongo of lower Zaire, Chicago: University of Chicago Press, 1986.

MARCUSSI, Alexandre. "Cativeiro e Cura: Experiências religiosas da escravidão atlântica nos calundus de Luzia Pinta, séculos XVII-XVIII" (Tese de doutorado, FFLCH-USP, 2015).

MENZ, Maximiliano. "A Companhia de Pernambuco e Paraíba e o funcionamento do tráfico de escravos em Angola (1759-1775/80)", Afro-Ásia (UFBA), v. 48, 2013, Pp. $45-76$.

MILLER, Joseph. “África Central durante a era do comércio de escravizados, de 1490 a 1850”, in Linda Heywood (org.). Diáspora negra no Brasil. São Paulo: Contexto, 2010, pp. 38-42.

MILLER, Joseph. Way of death merchant capitalism and the Angolan slave trade, 1730-1830. Madison: University of Wisconsin Press, 1988.

MINTZ, Sidney; PRICE, Richard. O nascimento da cultura afro-americana : uma perspectiva antropológica. Rio de Janeiro: Pallas, 2003.

MOTT, Luiz. "Acotundá: raízes setecentistas do sincretismo religioso afro-brasileiro", Anais do Museu Paulista, nova série, volume XXXI, São Paulo, 1986, pp. 124-147, p. 138

MOTT, Luiz. Rosa Egipcíaca: Uma Santa Africana no Brasil, Rio de Janeiro, Bertrand Brasil, 1993; Luiz Mott, "O calundu Angola de Luzia Pinta: Sabará, 1739", Revista do IAC, Ouro Preto, UFOP, n. 01, 1994.

PARES, Nicolau. A formação do candomblé : história e ritual da nação jeje na Bahia. Campinas: Editora Unicamp, 2006.

PARES, Nicolau. O pai, o rei e a morte: a religião Vodum na antiga Costa dos Escravos na África Ocidental. São Paulo: Companhia das Letras, 2017.

QUINTÃO, Antonia Aparecida. Lá vem o meu parente: as irmandades de pretos e pardos no Rio de Janeiro e em Pernambuco (século XVIII). São Paulo: Anablume, FAPESP, 2002.

REDIKER, Marcus. O navio negreiro: uma história humana. São Paulo: Companhia das Letras, 2011.

REGINALDO, Lucilene. Os Rosários dos Angolas: irmandades negras, experiências escravas e identidades africanas na Bahia setecentista" (Tese de Doutorado, IFCH-UNICAMP, 2005).

REIS, João José. Domingos Sodré, um sacerdote africano: escravidão, liberdade e candomblé na Bahia do século XIX. São Paulo: Companhia das Letras, 2008.

REIS, João. "Magia Jeje na Bahia: a invasão do calundu do Pasto de Cachoeira, 1785, Revista Brasileira de História, v. 8, n. 16, pp. 67-72, 1988.

REIS, João. A Morte é uma festa: ritos fúnebres e revolta popular no Brasil do século XIX. São Paulo: Companhia das Letras, 1991. 
SANTOS, Vanicléia Silva. "As bolsas de mandinga no espaço Atlântico: Século XVIII" (Tese de doutorado, FFLCH-USP, 2008).

SILVA JR., Carlos da "Interações atlânticas entre Salvador e Porto Novo (Costa da Mina) no século XVIII", Revista de História (USP), São Paulo, n. 176, pp. 1-41, 2017.

SILVA, Daniel Domingues da. The Atlantic Slave Trade from West Central Africa, 1780-1867. Cambridge: Cambridge University Press, 2017.

SILVA, Gian. "A presença de Africanos em Pernambuco: aspectos sobre escravidão, família e sociedade no período colonial, séculos XVI ao XIX", Revista Ultramares, v. 1, 2013, pp. 10-33.

SLENES, Robert. "Malungu, ngoma vem!: Africa coberta e descoberta do Brasil", Revista de História da USP, 1992 (12):48.

SLENES, Robert. "Metaphors to live by in the Diaspora: conceptual tropes and ontological wordplay among Central Africans in the Middle Passage and beyond", In: Ericka Abaugh, Luna Rathvyn (Orgs.). Tracing language movement in Africa. New York: Oxford University Press, 2018, pp. 343-364.

SOUZA, Laura de Mello e. Inferno Atlântico: Demonologia e Colonização (Séculos XVI-XVIII). São Paulo: Companhia das Letras, 1993.

SOUZA, Laura de Mello e. O Diabo e a Terra de Santa Cruz: feitiçaria e religiosidade popular no Brasil colonial, São Paulo: Companhia das Letras, 1986.

SOUZA, Marina de Mello e. Além do visível: poder, catolicismo e no Congo e em Angola (séculos XVI e XVII). São Paulo: EDUSP, 2018.

SOUZA, Marina de Mello e. Além do visivel: poder, catolicismo e no Congo e em Angola (séculos XVI e XVII). São Paulo: EDUSP, 2018.

SWEET, James. Domingos Alvares: African healing, and the intellectual history of the Atlantic world. Chapel Hill: University of North Carolina Press, 2011.

SWEET, James. Recriar Africa: cultura, parentesco e religião no mundo afro-portugues (14411770). Lisboa: Edições 70, 2007.

THORNTON, John. "The Development of an African Catholic Church in the Kingdom of Kongo, 1491-1750." The Journal of African History, 25 (2), 1984, pp. 147-167.

THORNTON, John. A África e os africanos na formação do mundo Atlântico 1400-1800. Rio de Janeiro: Elsevier, 2004. 
Normas observadas na transcrição do Sumário Contra os Pretos de Angola do Continente de Pernambuco:

1 A transcrição do sumário está dividida em duas versões, uma paleográfica e outra atualizada.

2 A numeração das folhas encontra-se entre colchetes e foi estabelecida da seguinte forma: no caso da folha frente, adotamos, os sinais "<1>r ", como no exmplo: [fl. $<1>$ r]. A numeração das folhas versos encontra-se entre colchetes sem os sinais " $<>$ "

3 Todas as quebras de linha do documento original estão marcadas pela barra vertica "|".

4 As abreviaturas não foram desdobradas na versão paleográfica, apenas na versão atualizada.

5 As letras maíusculas e minúsculas foram transcritas conforme original.

6 As letras sobrescritas foram mantidas.

7 As palavras cuja transcrição foi duvidosa ou encontravam-se em mau estado estão entre colchetes.

8 Os acentos e sinais gráficos do documento original foram preservados na versão paleográfica.

9 A versão atualizada adaptou a pontuação, os acentos e a ortografia do original para o português contemporâneo e desdobrou as abreviaturas.

\section{TRANSCRIÇÃO PALEOGRÁFICA}

[fl. $<1>$ r]

Summario contra os Prettos de

Angola do Continente de Per- |

Nambuco |

[fl.1v, em branco] 
$[\mathrm{fl} .<2>\mathrm{r}]$

\author{
Escreveo-se pela Meza ao Gover- | \\ nador daquelle Estado, para com | \\ as suas providencias se remedear | \\ a desordem, de que faz mençaõ a Re | \\ prezentaçaõ inclusa; em Carta com | \\ a data de 25 de Novembro de 1779 | \\ a qual Se acha Registada a fl 85.
}

[fl.2v, em branco]

[fl. $<3>$ r]

S. Pretos de Angolla.

Ill $^{\text {mos. }} S^{\text {rs. }}$

Da denuncia junta consta q os Pretos vindos a Per- |

nambuco do gentio de Angolla, e outros destrittos, se |

ajuntaõ e executaõ humas danças a companhadas |

de rittos gentilicos, como q aquelles bárbaros adorão |

as falças divindades; e outras qe incitaõ a actos tor- |

pes e obscenos; a cuja mad ocorrendo a vigilancia |

dos $\mathrm{P}^{\text {es. }}$ Missionarios, nada se conseguio, por se lhe $\mid$

opor o governador daq1 ${ }^{\text {a. }}$ cid $^{\text {e. }}$ fautorizando os per- $\mid$

versos Autores, permitindo-lhes aquelles escanda- |

lozos festejos, e punindo com penas pecuniarias | 
aos zelosos q $\mathrm{q}^{\mathrm{e}}$ ajudaraõ os Missionarios a fazer de- |

testar aqles. erros, e quebrar-lhes os instrumentos. |

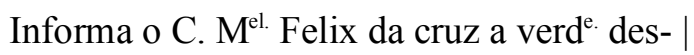

te cazo, e a desordem q e hirá aumentando- |

com os sobred ${ }^{\text {tos. }}$ festejos gentilicos; pois vendo os |

Pretos q o governador lhos permite, escarnea- |

do contrarios e dos mesmos $\mathrm{P}^{\text {es. }}$ Missionarios. |

Consta $q^{\mathrm{e}}$ os governadores já an ${ }^{\text {te. }} \mathrm{m}^{\text {nte. }}$ tinhaõ $\mid$

prohibido esta pestilente maldade, como de pre- |

$\mathrm{z}^{\text {te. }}$ expoem Luis Diogo Lobo, $\mathrm{q}^{\mathrm{e}}$ em substancia |

vem a dizer o mesmo q expressaõ a denuncia |

e informaçaõ incluzas. |

Todos os actos q os gentios executaõ como al- |

guma especie de Idolatria, saõ taõ abomina- |

veis, $\mathrm{q}^{\mathrm{e}}$ os mesmos hereges os aborresem, detes- |

taõ e castigaõ; a q assim se deve executar en- |

tre a christandade, pelo geral escandalo dos Fi- |

éis, $p^{\text {a. }}$ dar publicam ${ }^{\text {te. }}$ a conhecer o horror de se- |

milhante delicto, e $\mathrm{p}^{\mathrm{a}}$ se precaver $\mathrm{q}^{\mathrm{e}}$ aquelles mes- $\mid$

mos Pretos, depois de alcançarem a felicide. do- |

baptismo, e a saâ doutrina da Igra. catholica, naõ |

corraõ e se precipitem no horrivel cáos q $\mathrm{q}^{\mathrm{e}}$ lhes |

estava detriminado ao tempo da sua miseravel |

obscuridade; voltando-se por aquelle modo ao seu |

$a^{\text {to. }}$ e detestavel vomito. 


$$
\text { Requeiro [+/- } 1 \text { palavra corroída }] \text { a cus }{ }^{\text {as. }} \text { por } \mathrm{p}^{\text {te. }} \mathrm{da} \mid
$$

$[\mathrm{fl} .3 \mathrm{v}]$

$$
\begin{aligned}
& \text { da justiça, } q^{\text {e }} \text { vista a denu }-\mid \\
& \text { cia e conta do inclusas, e cõ | } \\
& \text { a circunspecçaõ q o cazo pe- | }
\end{aligned}
$$

de, se prova do remedio $\mathrm{q}^{\mathrm{e}} \mid$

pareser mais apto e pronto |

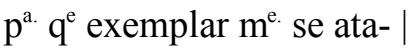

lhe e corte pela raiz taõ hor- $\mid$

roróza maldade. |

o Pronc ${ }^{\text {or. }}$ [MMollenRy ?]

Reprezentado em Meza o Requerimento |

Supra Ao Promotor para os Senhores |

Inquizitores the haverem de Defe |

rir, de seu mandado lhe fiz comclu |

za Gregorio Xavier Godinho a es |

crevi |

$\mathrm{C}^{\text {los }}$

$[$ fl. $<4>$ r $]$

Dénuncia ao Santo Officio | 
Se deve primeyro saber, que neste Pernambuco tem introduzido os negroz gentioz bap- | tizadoz huás danças das suas terras, com que lâ adoraõ, e festejão aoz seoz falsoz Deozes, | acompanhadas de inztrumentoz gentilicoz, tabaques, que saõ como especie de tambor, ma- | rimbas e outros de ferro, todoz estrondosoz, horriveis, triztes, e desentoadoz, proprioz do infer- | no, e certas cantillenas na sua lingua gentilica, as quaes em todoz oz Domingoz, e dias San- | toz do anno fazem, e se colôraõ com titulo de tirarem esmolla para nossa Senhora, | e para mandarem dizer missas pelas almas doz que morrem daquella sociedade, e o fazé | com certa meza cuberta com rito taó bem gentilico: o que tudo deve cauzar todo o re- | páro, e attenção, poiz se achaõ em terra christá, e elles baptizados. |

Algunz Governadores prohibîraõ estas danças, e outros, que se fazem na terra peloz | Natturaes, chamadas Foffa, ou Batuque entre homenz, e mulheres, que consizte em reprezen- | tar hum acto torpe de fornicaçaõ, acompanhada de inztrumentoz, estrepitoz, de pes, e maôz, | com ditoz inhonestoz, e para mayor desgraça noz tempoz prezentes com ditoz blasfemicoz, | como $=$ Oh meo Deoz, ora vamoz para o Ceo $=$ cujo toque, ou pessa por si sô ouvida noz inz-| trumentoz movem incentivos para deshonestidade ainda noz tementes a Deoz, quanto ma- | es nos mizeraveis peccadores: foraõ estes Henrique Luiz, D. Marcoz de Noronha, Luiz Di- | ogo Lobo, e o Conde de Pavolide. Fora desses correm impunes, maximá noz tempoz pre- | zentes, e no seo augmento, noz quaes o actual Governador naõ cura disso, e sem tem moz- | trado naõ so permissor, maximé das doz negroz, concedendo-lhes licença para isso | por despacho seo, mas taõ bem fautor, como se verâ do seguinte. |

Chegadoz oz RR. Missionarioz Capuchinhoz a esta terra, mandadoz pela nossa Fidelissima | Rainha, informadoz, e vendo as sobreditas danças, maximé a doz negroz, começaraõ a invehir | fervorozamente doz pulpitoz contra ellas, e Levadoz do seo Apoztolico espirito no dia vinte, e hum | de Dezembro de $\underline{1778}$ sahiraõ do Hospicio, acompanhadoz de sinco sacerdotes seculares, | e peloz lugares, que lhes ensinava o povo, a forsa de razões com hum Santo Christo re- | 
duzîraõ a huns a entregar a algunz doz ditoz inztrumentoz, que o povo pelo dito doz Mis- | sionarioz quebrâraõ, e queimâraõ. |

Gueyxâraõ-se oz outroz negroz no mesmo dia ao Governador, que lhes con- | cedêra a licença in scriptis, e no seguinte dia mandou intimar ordem aoz RR. Mis- | sionarioz de cessarem de tal facto sub pena de oz remeter para Lisboa a nossa Fidelis- | sima Rainha, como perturbadores da Republica: e condemnou aoz sinco sacerdotez | seculares, que oz acompanhâraõ, em tres mil reis cada hum, para a refaçaõ de instrumen- | toz quebradoz, por naõ terem oz Missionarioz com que pagar de que se exaltâraõ oz ne- | groz athe com ditterioz, e cantigas subsanarem pelas ruas aoz ditoz Missionarios, e solem- | nizarem as Festas do Santo Natal seguinte com especial concurso delles as taes dançaz: | e de mais a hum delles, que procurou ir a Lisboa dar conta a nossa Fidelissima Rainha, | houve tal embaraço, que naõ foi possível embarcar. |

E como vendo os Turcoz, que hum Chriztaõ arrenegado, andasse sempre a re | petir o Credo, Pater nozter, etc., e fazendo acções, e ritoz christaõz, prudentemente | o teriaõ por Christaõ, e naõ por Mouro, ou renegado: do mesmo modo vendo aoz | negroz gentioz baptizados no Chriztianismo com tanta frequencia, e publicidade ex- | ercitarem acções, cantillenas, ritoz, e festejoz da gentilidade, com que adorão aoz se- | oz falsoz Deozes, prudentemente se pode suspeytar, e temer, que estejão Christaõz |

sendo

Sendo oz mesmoz, que eraõ, quando gentioz. |

E naõ achando huá cauza de tanto porte, e pezo de nossa Religiaõ Christã re- | medio para se evitar nesta terra; porque, como disse, o Governador concede, e fau- | tua: oz Missionarioz em lugar de remediar, ficâraõ atalhadoz, abatidoz e impedi- | doz para ir dar conta a nossa Fidelissima Rainha: eu Domingos de Oliveira Marques | 
Sacerdote do habito de Sam Pedro, natural, e morador nesta Villa de Santo Antonio | do Reciffe de Parnambuco, por ser publico, e notorio o memorado facto nesta terra, | e por o ter prezenciado, e ser hum dos sinco, que acompanhâraõ aoz Missionarioz, | e que paguei oz tres mil Reiz da condemnaçaõ, levado unicamente, e movido da | honra de Deoz, e da nossa Religiaõ Christã, o denuncio ao Santo Officio, para lhe | por o remedio, nesta mesma $\mathrm{V}^{\mathrm{a} .}$ Do $\mathrm{R}^{\text {ce. }}$ aoz 10 de Fevereiro de $1779 \mid$

\section{Domingoz de Olivr. Marquez}

[fl. $<5>$ r]

$$
\text { Illm. }{ }^{\mathrm{oz}} \mathrm{Rm} .{ }^{\mathrm{oz}} \text { Snres }
$$

Há tempo, que ando escrupulo, e dezejozo de dar conta a V. Rmª | de um abuzo, que se tem introduzido neste Pern. ${ }^{\text {oo }}$, e agora com ma | yor rezão pelo facto de $\mathrm{q}^{\mathrm{e}}$ faz mençaõ a denuncia incluza. |

Os negroz do Genthio de Angolla, especialm. oz do Gentio da Cozta | custumaõ, quando morre algum seu parente, ou malungo, pôr | publicam. ${ }^{\text {te }}$ nas praçaz, e outroz lugares huma meza coberta com huma | baeta preta a pedirem esmolla p. ${ }^{\mathrm{a}}$ mandar dizer missaz por alma do | tal parente, ou malungo, que falleceo, (athe aqui acto de piedade), | porem nessa mesma ocaziaõ se ajuntaõ huas, e outroz de diverso sexo | e a roda da meza fazem huma dança ao modo de sua terra com | huas tabaques, e outroz instrumentoz [funebrez], que na verdade naõ he | outra couza maes de que hum rito dece gentilico; e o qe mais he, que | o Snr Governado consente, e lhes da Licença p. isto, e p. ${ }^{\mathrm{r}}$ outras danças | e batuques, que actualmt. ${ }^{\text {e }}$ fasem aoz domingoz e dias santoz uzando | 
nesta sua danca de cantinellas, e palavraz escandalozas, donde re |

zultou o facto, que contem a denuncia inclusa, que toda he ver |

deira.

He cousa na verdade mt. ${ }^{\circ}$ alheia, que nomeio de Chris- |

tandade se consintaõ semelhantes dançaz, que não parecem outra |

couza, q ritoz gentilicoz oppoztos a Santa fé e Religão Christan; |

e como esta cousaz cheiraõ mt. ${ }^{\circ}$ mal dou conta a v. $\mathrm{Rm}^{\text {as }}$ com $\mid$

a denuncia inclusa, $p{ }^{\text {a }}$ que possaõ dar a providencia, como fo- |

rem servidoz. D.s G. ${ }^{\text {de }}$ a v. ${ }^{\text {s }}$ Rm. ${ }^{\text {as }}$ mil annoz. Boavysta de |

Abril 8 de 1779|

De V. Rm. ${ }^{\text {as }}$

Fiel e sbdito e atento ven ${ }^{\text {or. }}$

$\underline{\text { Manoel Felix da Cruz }}$

[f15v, em branco]

\section{TRANSCRIÇÃO ATUALIZADA}

$[$ capa $]$

Sumário contra os Pretos de Angola do Continente de Pernambuco

[fl.1v, em branco]

$[\mathrm{fl} .<2>\mathrm{r}]$

Escreveu-se pela Mesa ao Governador daquele Estado, para com as suas providências se remediar a desordem, de que faz menção a representação inclusa em carta com a data de 25 de Novembro de 1779, a qual se acha registrada a folha 85 .

$[\mathrm{fl} .2 \mathrm{v}$, em branco]

$[\mathrm{fl} .<3>\mathrm{r}]$ 
Sumário Pretos de Angola

Ilustríssimos Senhores

Da denúncia junta consta que os Pretos vindos a Pernambuco do gentio de Angola, e outros distritos, se ajuntam e executam umas danças acompanhadas de ritos gentílicos, como que aqueles bárbaros adoram as falsas divindades e outras que incitam a atos torpes e obscenos; a cuja maldade ocorrendo a vigilância dos padres missionários nada se conseguiu, por se lhe opor o governador daquela cidade fautorizando os perversos autores, permitindo-lhes aqueles escandalosos festejos e punindo com penas pecuniárias aos zelosos que ajudaram os missionários a fazer detestar aqueles erros, e quebrar-lhes os instrumentos.

Informa o Comissário Manoel Félix da Cruz a verdade deste caso e a desordem que se irá aumentando com os sobreditos festejos gentílicos, pois vendo os pretos que o governador lhos permite, escarneiam do contrário e dos mesmos padres missionários.

Consta que os governadores já [anteriormente] tinham proibido esta pestilente maldade, como de presente expõem Luis Diogo Lobo, que em substância vem a dizer o mesmo que expressam a denúncia e informação inclusa.

Todos os atos que os gentios executam com alguma espécie de idolatria são tão abomináveis que os mesmos hegeres os aborrecem, detestam e castigam; o que assim se deve executar entre a cristandade, pelo geral escândalo dos fiéis para dar publicamente a conhecer o horror de semelhante delito e para se precaver que aqueles mesmos pretos, depois de alcançarem a felicidade do batismo e a sã doutrina da igreja católica, não corram e se precipitem no horrível caos que lhes estava determinado ao tempo da sua miserável obscuridade, voltando-se por aquele modo ao seu [antigo] e detestável vômito.

Portanto

Requeiro [+/- 1 palavra corroída] [A Vossas Senhorias] por parte da।

$[\mathrm{fl} .3 \mathrm{v}]$

da justiça, que vista a denúncia e conta do [sic] inclusas com a circunspecção que o caso pede, se prova do remédio que parecer mais apto e pronto para que exemplarmente se atalhe e corte pela raiz tão horrorosa maldade.

\section{o Promotor [Moller]}

[Re]presentado em Mesa o requerimento supra do promotor para os senhores inquisidores lhe haverem de deferir, de seu mandado lho fiz com clareza Gregorio Xavier Godinho o escrevi.

$\left[\mathrm{C}^{\text {los}}\right]$ 
[fl. $<4>$ r]

\section{Denúncia ao Santo Ofício}

Se deve primeiro saber que neste Pernambuco tem introduzido os negros gentios batizados umas danças das suas terras, com que lá adoram e festejam aos seus falsos deuses, acompanhadas de instrumentos gentílicos, atabaques, que são como espécie de tambor, marimbas e outros de ferro, todos estrondosos, horríveis, tristes e desentoados, próprios do inferno, e certas cantilenas na sua língua gentílica, as quais em todos os domingos e dias santos do ano fazem, e se coloram com título de tirarem esmola para Nossa Senhora, e para mandarem dizer missas pelas almas dos que morrem daquela sociedade. E o fazem com certa mesa coberta com rito também gentílico: o que tudo deve causar todo o reparo e atenção, pois se acham em terra cristã e eles batizados.

Alguns governadores proibiram estas danças e outras que se fazem na terra pelos naturais, chamadas fofa, ou batuque entre homens e mulheres, que consiste em representar um ato torpe de fornicação, acompanhada de instrumentos, estrépitos de pés e mãos, com ditos desonestos. E para maior desgradaça, nos tempos presentes, com ditos blasfêmicos, como "Oh meu Deus, ora vamos para o céu", cujo toque ou peça por si só ouvida nos instrumentos movem incentivos para desonestidade ainda nos tementes a Deus, quanto mais miseráveis pecadores. Foram estes Henrique Luiz, D. Marcos de Noronha, Luiz Diogo Lobo, e o Conde de Pavolide. Fora desses correm impunes, maximá nos tempoz presentes e no seu aumento, nos quais o atual governador não cura disso e se tem mostrado não só permissor, maximé das dos negros, concedendo-lhes licença para isso por despacho seu, mas também fautor, como se verá do seguinte.

Chegados os reverendos missionários capuchinhos a esta terra, mandados pela nossa Fidelíssima Rainha, informados e vendo as sobreditas danças, máxime a dos negros, começaram a invehir fervorosamente dos púlpitos contra elas, e levados do seu apostólico espírito no dia vinte e um de dezembro de 1778 sairam do Hospício, acompanhados de cinco sacerdotes seculares, e pelos lugares que lhes ensinava o povo, a força da razão com um santo Cristo reduziram a uns a entregar a alguns dos ditos instrumentos, que o povo pelo dito dos missionários quebraram e queimaram.

Queixaram-se os outros negros no mesmo dia ao governador, que lhes concedera a licença in scriptis, e no seguinte dia mandou intimar ordem aos reverendos missionários de cessarem de tal fato sob pena de os remeter para Lisboa à nossa Fidelíssima Rainha como perturbadores da República. E condenou aos cinco sacerdotes seculares que os acompanharam em três mil réis cada um para refação de instrumentos quebrados por não terem os missionários com que pagar de que exaltaram os negros até com ditérios e cantigas subsanarem pelas ruas aos ditos missionários e solenizarem as festas do Santo Natal seguinte com especial concurso deles às tais danças. E a demais a um deles, que procurou ir a Lisboa dar conta à nossa Fidelíssima Rainha, houve tal embaraço que não foi possível embarcar.

E como vendo os turcos que um cristão arrenegado andasse sempre a repetir o Credo Pater Noster, etc, e fazendo ações e ritos cristãos, prudentemente o teriam por cristão e não por mouro ou renegado. Do mesmo modo, vendo aos negros gentios batizados no Cristianismo com tanta frequência e publicidade exercitarem ações, cantilenas e ritos e festejos da gentilidade com que adoram aos seus falsos deuses, prudentemente se pode suspeitar e temer que estejam cristão sendo 
$[\mathrm{fl} .4 \mathrm{v}]$

sendo os mesmos que eram quando gentios.

E não achando uma coisa de tanto porte e peso de nossa religião cristã remédio para se evitar nesta terra; porque, como disse, o governador concede e fautua, os missionários, em lugar de remediar, ficaram atalhados, abatidos e impedidos para ir dar conta à nossa Felicíssima Rainha. Eu, Domingos Marques de Oliveira, Sacerdote do hábito de São Pedro, natural, e morador nesta Vila de Santo Antônio do Reciffe de Parnambuco, por ser público e notório o memorado fato nesta terra e por o ter presenciado e ser um dos cinco que acompanharam aos missionários e que paguei os três mil réis da condenação, levado unicamente e movido da honra de Deus e da nossa religião cristã, o denuncio ao Santo Ofício para lhe por o remédio. Nesta mesma vila do Recife, aos 10 de fevereiro de 1779.

$[\mathrm{fl} .<5>\mathrm{r}]$

Domingos de Oliveira Marques

Ilustríssimos Reverendíssimos Senhores

Há tempo que ando escrúpulo e desejoso de dar conta à Vossa Reverendíssima de um abuso que se tem introduzido neste Pernambuco, e agora com maior razão pelo fato que faz menção a denúncia inclusa.

Os negros do gentio de Angola, especialmente os do Gentio da Costa, costumam, quando morre algum seu parente ou malungo, por publicamente nas praças e outros lugares uma mesa coberta com uma baeta preta a pedirem esmola para mandar dizer missas por alma do tal parente ou malungo que faleceu (até aqui ato de piedade). Porém, nessa mesma ocasião se ajuntam umas e outros de diverso sexo e à roda da mesa fazem uma dança ao modo de sua terra com uns atabaques e outros instrumentos fúnebres, que, na verdade, não é outra coisa mais do que um rito seu gentílico. E o que mais é que o senhor governador consente e lhes dá licença para isto e para outras danças e batuques que atualmente fazem aos domingos e dias santos usando nesta sua dança de cantinelas e palavras escandalosas, donde resultou o fato que contém a denúncia inclusa, que toda é verdadeira.

É coisa, na verdade, muito alheia que no meio da cristandade se consintam semelhantes danças que não parecem outra coisa que ritos gentílicos opostos à santa fé e religião cristã; e como estas coisas cheiram muito mal desse conta a Vossas Reverendíssimas com a denúncia inclusa para que possam dar a providência, como forem servido.

Deus guarde a Vossas Reverendíssimas muitos anos. Boa Vista de Abril 8 de 1779.

De Vossas Reverendíssimas

Fiel Súdito e atento venerador

Manoel Félix da Cruz

[f15v, em branco] 